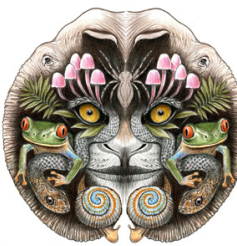

ISSN 0974-7907 (Online) ISSN 0974-7893 (Print)

OPEN ACCESS

\title{
DRAGONFLIES AND DAMSELFLIES (INSECTA: OdONATA) OF NAGALAND, WITH AN ADDITION TO THE INDIAN ODONATE FAUNA
}

\author{
Shantanu Joshi ${ }^{1} \&$ Krushnamegh Kunte ${ }^{2}$
}

1,2 Indian Foundation for Butterflies. C-703, Alpine Pyramid, Rajiv Gandhi Nagar, Bengaluru, Karnataka 560092, India. ${ }^{1}$ Department of Zoology, St. Xavier's College-Autonomous, Mumbai, Maharashtra, 400001, India ${ }^{2}$ National Center for Biological Sciences, Tata Institute of Fundamental Research, GKVK, Bellary Road, Bengaluru, Karnataka 560065, India

${ }^{1}$ shantanu@ifoundbutterflies.org (corresponding author), krushnamegh@ncbs.res.in

Abstract: We surveyed odonates in the districts of Kohima, Peren and Wokha in the state of Nagaland, northeastern India, during April and May 2012 and May 2013. We recorded 69 species, including 43 additions to the known odonates of Nagaland, and one additionCalicnemia erythromelas Selys, 1891-to the Indian odonate fauna. The known odonate fauna of Nagaland now consists of 90 species in 53 genera and 14 families. We also describe for the first time the female of Coeliccia schmidti, and partially, a heterochromatic form of the female Ischnura mildredae.

Keywords: Anisoptera, Indo-Burmese Biodiversity Hotspot, northeastern India, species inventories, Zygoptera.
Nagaland is one of the seven northeastern states of India with a geographical area of $16,527 \mathrm{~km}^{2}$, of which approximately $56 \%$ is forested (Forest Survey of India 2009). Of these, forests on only $222 \mathrm{~km}^{2}$, or $1.34 \%$ of the state's geographical area, are protected as the state's only national park and three wildlife sanctuaries (Forest Survey of India 2009), the remaining majority lie on community-owned land. As part of the globally recognized Indo-Burmese Biodiversity Hotspot, Nagaland boasts remarkable faunal and floral diversity,
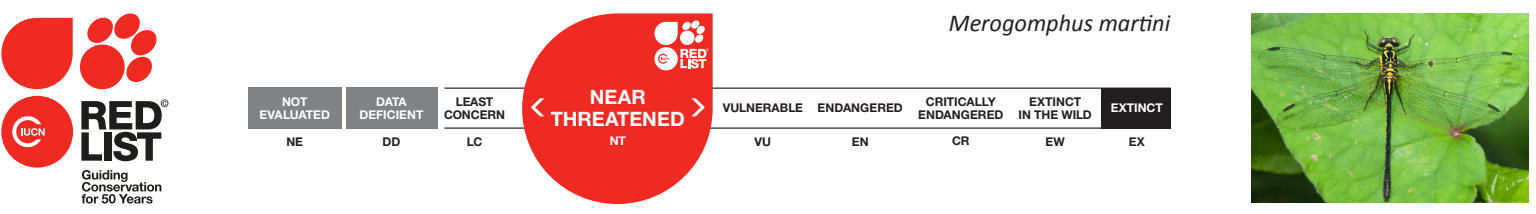

DOI: http://dx.doi.org/10.11609/JoTT.o3911.6458-72 | ZooBank: urn:Isid:zoobank.org:pub:87168D82-8DC7-4E65-B540-271B470EC408

Editor: K.A. Subramanian, Zoological Survey of India, Kolkata, India.

Date of publication: 26 October 2014 (online \& print)

Manuscript details: Ms \# 03911 | Received 09 January 2014 | Final received 11 September 2014 | Finally accepted 20 September 2014

Citation: Joshi, S. \& K. Kunte (2014). Dragonflies and damselflies (Insecta: Odonata) of Nagaland, with an addition to the Indian odonate fauna. Journal of Threatened Taxa 6(11): 6458-6472; http://dx.doi.org/10.11609/JoTT.o3911.6458-72

Copyright: ( Joshi \& Kunte 2014. Creative Commons Attribution 4.0 International License. JoTT allows unrestricted use of this article in any medium, reproduction and distribution by providing adequate credit to the authors and the source of publication.

Funding: This work was supported by research grants to KK through a Ramanujan Fellowship (Dept. of Science and Technology, Govt. of India) and the Startup Grant from NCBS.

Competing Interest: The authors declare no competing interests.

Acknowledgements: Thanks are due to Tarun Karmarkar, Benjamin Price and Suman Attiwilli for assistance in the field, K.A. Subramanian, Oleg Kosterin and Saurabh Sawant for help with literature and initial review of the manuscript, Matti Hämäläinen and Noppadon Makbun for identification of a few species, and the Bombay Natural History Society for stereomicroscopy facilities. We especially thank Bano Haralu for hosting us in Nagaland and facilitating field work. This work was supported by research grants to KK through a Ramanujan Fellowship (Dept. of Science and Technology, Govt. of India) and the Startup Grant from NCBS, and necessary permits from the Chief Wildlife Warden, Department of Forests, Ecology, Environment and Wildlife, Govt. of Nagaland (permit no. CWL/GEN/240/52239), and the Dzulekie Village Council, Kohima District, Nagaland. This is publication no. 9 of the Indian Foundation for Butterflies (http://www.ifoundbutterflies. org/). Subsequent information on the odonates of Nagaland may be found at the Odonata of India website (http://www.indianodonata.org//
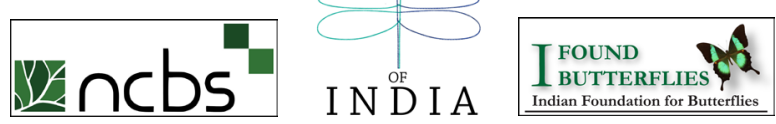
including many rare, endemic and legally protected species of megafauna and largely undocumented components of insect and plant biodiversity (Grewal et al. 2012). Due to remoteness, biodiversity of Nagaland had been understudied until recently. The state is now considerably accessible, attracting many ecologists and conservation biologists. In the past few years, biodiversity surveys in Nagaland have revealed an impressive concentration of species of national and international conservation importance (Grewal et al. 2012).

Any comparative work involving historical information on Nagaland biodiversity along with the current distribution and state of biodiversity faces a peculiar challenge. Until statehood was conferred in 1963, Nagaland was part of the erstwhile state of Assam, which at that time covered most of northeastern India that is now divided into seven states. Hence, most of the historical (mostly British) records were generally subsumed under "Assam", and only in rare cases were specific localities mentioned. Specific locality records are potentially available from many specimen labels, which have not been studied very well with reference to modern state and national boundaries in this part of the Indian Subcontinent. Therefore, the exact distribution of species in these states is currently poorly documented, especially for invertebrates. This problem is particularly acute for dragonflies and damselflies (Insecta: Odonata), which have not been surveyed extensively in northeastern India. Fraser (1933, 1934, 1936) mentioned Naga Hills when characterising the distribution of several species. Since then, Mitra (2002) has done the most comprehensive work on odonates of northeastern India, including a review of all the existing literature. Lahiri $(1987,1977)$ made notable contributions to odonates of Meghalaya and Manipur. The most recent and complete work is by Subramanian (2009), who presented a taxonomically updated checklist of Indian odonates. Nonetheless, much work needs to be done in northeastern India, and we especially require specific locality and bionomic information. The present paper is an effort at providing important information on the natural history, distributions, and status of odonates of Nagaland.

\section{MATERIALS AND MethodS}

We opportunistically surveyed odonates on random walks along forest paths, roads and streams in the districts of Kohima, Peren and Wokha in Nagaland (Table 1, Image 1). We photographed specimens for

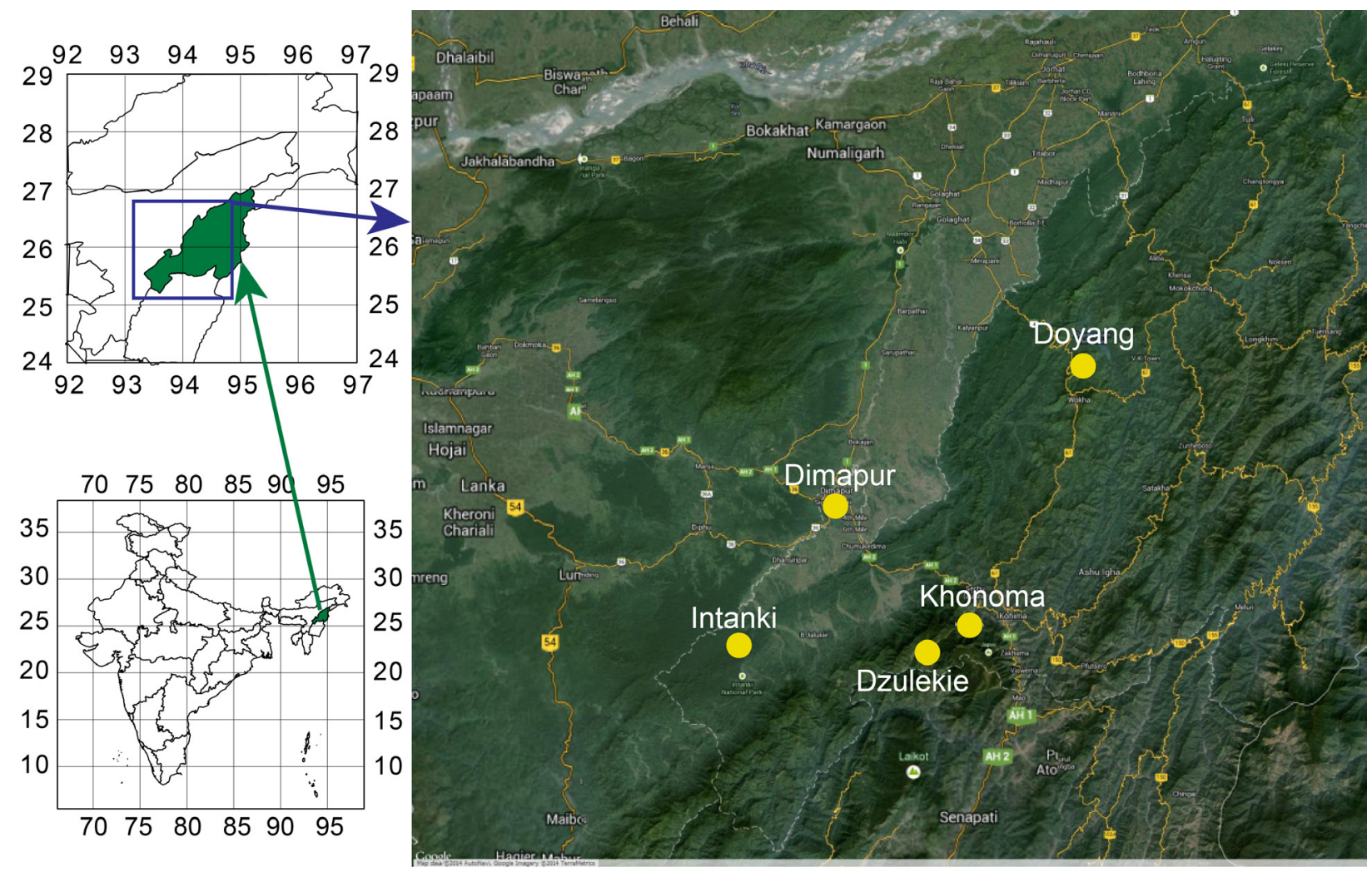

Image 1. A reference map of India with the study localities highlighted 
Table 1. Details of the survey localities in Nagaland.

\begin{tabular}{|c|l|l|l|l|l|l|l|}
\hline & Locality & GPS co-ordinates & District & Dates visited & Altitude & Habitat \\
\hline species
\end{tabular}

Table 2. Details of the voucher specimens mentioned in this paper, all deposited in the Research Collections Facility at the National Center for Biological Sciences, Bengaluru, India

\begin{tabular}{|l|l|l|l|c|}
\hline Species & Sex & Date of collection & Locality & Accession Number \\
\hline Chloropetalia selysi & Female & 14 May 2013 & Khonoma & NCBS-AE273 \\
\hline Chloropetalia selysi & Male & 14 May 2013 & Khonoma & NCBS-AE275 \\
\hline Burmagomphus hashimaricus & Male & 20 May 2013 & Intanki NP & NCBS-AE297 \\
\hline Burmagomphus hashimaricus & Female & 24 May 2013 & Intanki NP & NCBS-AE326 \\
\hline Merogomphus martini & Male & 10 May 2013 & Wokha & NCBS-AE224 \\
\hline Merogomphus martini & Male & 12 May 2013 & Wokha & NCBS-AE241 \\
\hline Merogomphus martini & Male & 12 May 2013 & Wokha & NCBS-AE244 \\
\hline Stylogomphus sp. & Male & 12 May 2013 & Wokha & NCBS-AE240 \\
\hline Ceriagrion rubiae & Male & 24 May 2013 & Intanki NP & NCBS-AE325 \\
\hline Ischnura mildredae & Male & 13 May 2013 & Khonoma & NCBS-AE252 \\
\hline Ischnura mildredae & Female & 13 May 2013 & Khonoma & NCBS-AE258 \\
\hline Ischnura mildredae & Female & 14 May 2013 & Khonoma & NCBS-AE265 \\
\hline Ischnura mildredae & Male & 14 May 2013 & Khonoma & NCBS-AE266 \\
\hline Ischnuramildredae & Female & 14 May 2013 & Khonoma & NCBS-AE267 \\
\hline Calicnemia erythromelas & Male & 17 May 2013 & Khonoma & NCBS-AE285 \\
\hline Elattoneura coomansi & Male & 20 May 2013 & Intanki NP & NCBS-AE294 \\
\hline Elattoneura coomansi & Female & 20 May 2013 & Intanki NP & NCBS-AE298 \\
\hline Elattoneura coomansi & Female & 20 May 2013 & Intanki NP & NCBS-AE299 \\
\hline
\end{tabular}

various identification features in the field. We took voucher specimens where necessary after obtaining required research and collecting permits for protected areas of the state from the Department of Forests, Ecology, Environment and Wildlife, Government of Nagaland (permit no. CWL/GEN/240/522-39), and permission from local village councils on community land. Voucher specimens (Table 2) are deposited in the Research Collections Facility at the National Center for Biological Sciences (NCBS), Bengaluru, India. We identified these specimens mainly with the help of keys provided by Fraser (1933, 1934, 1936), Laidlaw (1950), Asahina (1967, 1984), Vick (1986), Mitra (2002), and Nair (2011). We followed odonate taxonomy and binomial names by Subramanian (2009), except for Chloropetalia Carle, 1995 in place of Chlorogomphus Selys, 1854
(Schorr \& Paulson 2009), and Aristocypha Laidlaw, 1950 and Heliocypha Fraser, 1949 instead of Rhinocypha Rambur, 1842 (as used in Subramanian 2014). Family classification followed Subramanian (2014) and Dijkstra et al. (2013).

\section{RESULTS AND DISCUSSION}

We recorded 68 odonate species from 13 familes and from 54 genera; from Nagaland, including 42 species previously not reported from the state, and one species-Calicnemia erythromelas Selys, 1891is an addition to the Indian odonate fauna (Table 3). We also observed Ceriagrion rubiae Laidlaw, 1916 in Intanki, which is the first formal record of the species from northeastern India. The known odonate fauna of Nagaland now consists of 90 species classified in 53 
Table 3. Checklist of Odonata of Nagaland. Localities: 1 - Doyang; 2 - Dzulekie; 3 - Intanki; 4 - Khonoma. Column 5 indicates species recorded by Mitra et al. (2006) but not recorded by us. The last column lists species recorded by Mitra et al. (2006). Species new to Nagaland are marked with asterisks (*). The only species new to India (Calicnemia erythromelas) is in bold letters).

\begin{tabular}{|c|c|c|c|c|c|c|c|}
\hline & Species Name & 1 & 2 & 3 & 4 & 5 & Mitra et al. 2006 \\
\hline & Aeshnidae & & & & & & \\
\hline 1 & Anax nigrofasciatus Fraser, 1935 & & & & & + & + \\
\hline 2 & Gynacantha bainbriggei Fraser, 1922* & + & & + & & & \\
\hline \multirow[t]{2}{*}{3} & Gynacantha bayadera Selys, 1891 & & & & & + & + \\
\hline & Chlorogopmhidae & & & & & & \\
\hline \multirow[t]{2}{*}{4} & Chloropetalia selysi Fraser 1929* & & & & + & & \\
\hline & Cordulegasteridae & & & & & & \\
\hline \multirow[t]{2}{*}{5} & Anotogaster nipalensis Selys, $1854^{*}$ & & & & + & & \\
\hline & Genera IncertaeSedis & & & & & & \\
\hline \multirow[t]{2}{*}{6} & Idionyx stevensi Fraser, 1924* & & & & + & & \\
\hline & Gomphidae & & & & & & \\
\hline 7 & Burmagomphus hasimaricus Fraser, 1926* & & & + & & & \\
\hline 8 & Merogomphus martini (Fraser, 1922) * & & & & + & & \\
\hline 9 & Stylogomphus sp.* & & & & + & & \\
\hline 10 & Paragomphus lineatus (Selys, 1850) * & & & + & & & \\
\hline \multirow[t]{2}{*}{11} & Nepogomphus modestus (Selys, 1878) & & & & & + & + \\
\hline & Libellulidae & & & & & & \\
\hline 12 & Acisoma panorpoides Rambur, 1842 & & & + & & & + \\
\hline 13 & Brachydiplax chalybea Brauer, $1868^{*}$ & & & + & & & \\
\hline 14 & Brachydiplax sobrina (Rambur, 1842) & & & + & & & + \\
\hline 15 & Brachythemis contaminata (Fabricius, 1793) & + & & + & & & + \\
\hline 16 & Camacinia gigantea (Brauer, 1867) & & & & & + & + \\
\hline 17 & Cratilla lineata Foerster, 1903* & + & & + & & & \\
\hline 18 & Crocothemis servilia (Drury, 1770) & + & + & + & + & & + \\
\hline 19 & Diplacodes trivialis (Rambur, 1842) & + & & + & & & + \\
\hline 20 & Diplacodes nebulosa (Fabricius, 1793) * & & & + & & & \\
\hline 21 & Lathrecista asiatica (Fabricius, 1798) & & & & & + & + \\
\hline 22 & Lyriothemis bivittata (Rambur, 1842) * & & & + & & & \\
\hline 23 & Neurothemis intermedia (Rambur, 1842) & & & + & & & + \\
\hline 24 & Neurothemis fulvia (Drury, 1773) & + & & + & & & + \\
\hline 25 & Neurothemis tullia (Drury, 1773) & & & + & & & + \\
\hline 26 & Onychothemis testacea Laidlaw, 1902* & & & + & & & \\
\hline 27 & Orthetrum glaucum (Brauer, 1865) & & & + & & & + \\
\hline 28 & Orthetrum japonicum (Uhler, 1858) & + & + & & + & & + \\
\hline 29 & Orthetrum luzonicum (Brauer, 1868) & & & + & & & + \\
\hline 30 & Orthetrum pruinosum (Burmeister, 1839) & + & + & + & + & & + \\
\hline 31 & Orthetrum sabina (Drury, 1770) & & & + & & & + \\
\hline 32 & Orthetrum taeniolatum (Schneider, 1845) & & & & & + & + \\
\hline 33 & Orthetrum triangulare (Selys, 1878) & + & + & & + & & + \\
\hline 34 & Palpopleura sexmaculata (Fabricius, 1787) & & & + & & & + \\
\hline 35 & Pantala flavescens (Fabricius, 1798) & + & + & + & + & & + \\
\hline 36 & Potamarcha congener (Rambur, 1842) & & & + & & & + \\
\hline 37 & Rhyothemis plutonia Selys, 1883* & & & + & & & \\
\hline 38 & Rhyothemis variegata (Linnaeus, 1763) * & & & + & & & \\
\hline 39 & Tetrathemis platyptera Selys, $1878^{*}$ & & & + & & & \\
\hline
\end{tabular}




\begin{tabular}{|c|c|c|c|c|c|c|c|}
\hline & Species Name & 1 & 2 & 3 & 4 & 5 & Mitra et al. 2006 \\
\hline 40 & Tholymis tillarga (Fabricius, 1798) & & & + & & & + \\
\hline 41 & Tramea basilaris (Palisot de Beauvois, 1805) * & & & + & & & \\
\hline 42 & Trithemis aurora (Burmeister, 1839) * & + & & + & + & & \\
\hline 43 & Trithemis festiva (Rambur, 1842) * & & & + & & & \\
\hline \multirow[t]{2}{*}{44} & Trithemis pallidinervis (Kirby, 1889) & & & + & & & + \\
\hline & Calopterygidae & & & & & & \\
\hline 45 & Caliphaea confusa Hagen in Selys, $1859^{*}$ & & + & & + & & \\
\hline 46 & Echo margarita Selys, 1853 & & & & & + & + \\
\hline 47 & Matrona nigripectus Selys, $1879^{*}$ & & & + & & & \\
\hline \multirow[t]{2}{*}{48} & Neurobasis chinensis (Linnaeus, 1758) & & & + & & & + \\
\hline & Chlorocyphidae & & & & & & \\
\hline 49 & Libellago lineata (Burmeister, 1839) * & & & + & & & \\
\hline 50 & Heliocypha biforata Selys, $1859 *$ & & & + & & & \\
\hline 51 & Heliocypha perforata Selys, 1879 & & & & & + & + \\
\hline 52 & Aristocypha quadrimaculata Selys, 1853 & + & & & & & + \\
\hline 53 & Aristocypha spuria Selys, 1879 & & & & & + & + \\
\hline \multirow[t]{2}{*}{54} & Aristocypha trifasciata Selys, 1853 & & & & & + & + \\
\hline & Coenagrionidae & & & & & & \\
\hline 55 & Aciagrion approximans (Selys, 1876) & & & & + & & + \\
\hline 56 & Aciagrion occidentale Laidlaw, 1919* & & & + & & & \\
\hline 57 & Aciagrion pallidum Selys, $1891^{*}$ & & & + & & & \\
\hline 58 & Agriocnemis lacteola Selys, $1877^{*}$ & & & + & & & \\
\hline 59 & Agriocnemis femina (Brauer, 1868) * & & & + & & & \\
\hline 60 & Agriocnemis pygmaea (Rambur, 1842) & & & . & + & & + \\
\hline 61 & Ceriagrion coromandelianum (Fabricius, 1798) & & & + & & & + \\
\hline 62 & Ceriagrion fallax Ris, 1914* & & & . & + & & \\
\hline 63 & Ceriagrion praetermissum Lieftinck, 1929 & & & . & & + & + \\
\hline 64 & Ceriagrion olivaceum Laidlaw, 1914* & & & + & & & \\
\hline 65 & Ceriagrion rubiae Laidlaw, 1916* & & & + & & & \\
\hline 66 & Ischnura aurora (Brauer, 1865) & & & + & & & + \\
\hline 67 & Ischnura senegalensis (Rambur, 1842) & & & & & + & + \\
\hline 68 & Ischnura rufostigma Selys, 1876 & & & & & + & + \\
\hline 69 & Ischnura mildredae Fraser, 1927* & & & & + & & \\
\hline 70 & Mortonagrion aborense (Laidlaw, 1914)* & & & + & & & \\
\hline 71 & Pseudagrion australasiae Selys, 1876 & & & & & + & + \\
\hline 72 & Pseudagrion rubriceps Selys, 1876 & + & & + & & & + \\
\hline \multirow[t]{2}{*}{73} & Onychargia atrocyana (Selys, 1865) & & & & & + & + \\
\hline & Euphaeidae & & & & & & \\
\hline 74 & Anisopleura comes Hagen, 1880 & & & & & + & + \\
\hline \multirow[t]{2}{*}{75} & Euphaea masoni Selys, 1879 & & & & & + & + \\
\hline & Lestidae & & & & & & \\
\hline 76 & Indolestes cyaneus (Selys, 1862) * & & + & & & & \\
\hline \multirow[t]{2}{*}{77} & Lestes dorothea Fraser, 1924* & & & + & & & \\
\hline & Lestes praemorsus Hagen in Selys, $1862^{*}$ & & & + & & & \\
\hline 78 & Platycnemididae & & & & & & \\
\hline 79 & Calicnemia eximia (Selys, 1863) & & & & & + & + \\
\hline 80 & Calicnemia imitans Lieftinck, $1948 *$ & + & & & & & \\
\hline
\end{tabular}




\begin{tabular}{|c|l|c|c|c|c|c|c|}
\hline & Species Name & $\mathbf{1}$ & $\mathbf{2}$ & $\mathbf{3}$ & $\mathbf{4}$ & $\mathbf{5}$ & Mitra et al. 2006 \\
\hline 81 & Calicnemia erythromelas (Selys, 1891)* & & & & + & & \\
\hline 82 & Calicnemia pulverulans (Selys, 1886) & & & & & + & + \\
\hline 83 & Coeliccia didyma (Selys, 1863) & + & & & & & + \\
\hline 84 & Coeliccia vacca Laidlaw, 1932 & & & & & + & + \\
\hline 85 & Coeliccia schmidti Asahina, 1984* & & & + & & & \\
\hline 86 & Copera ciliata (Selys, 1863) * & & & + & & & \\
\hline 87 & Copera superplatypes Fraser, 1927 & & & & & + & + \\
\hline 88 & Copera marginipes (Rambur, 1842) * & & & + & & & \\
\hline 89 & Elattoneura coomansi Lieftinck, 1937* & & & + & & & \\
\hline & Platystictidae & & & & & & \\
\hline 90 & Protosticta himalaica Laidlaw, 1917* & & & & + & & \\
\hline
\end{tabular}

Table 4. A taxonomic summary of odonates of Nagaland

\begin{tabular}{|c|c|c|}
\hline \multicolumn{3}{|c|}{ Sub-order Anisoptera } \\
\hline Family & Genus & No. of species \\
\hline \multirow[t]{3}{*}{ Aeshnidae } & & 3 \\
\hline & Anax & 1 \\
\hline & Gynacantha & 2 \\
\hline \multirow[t]{2}{*}{ Corduliidae } & & 1 \\
\hline & Idionyx & 1 \\
\hline \multirow[t]{2}{*}{ Cordulegasteridae } & & 1 \\
\hline & Anotogaster & 1 \\
\hline \multirow[t]{2}{*}{ Chlorogopmhidae } & & 1 \\
\hline & Chloropetalia & 1 \\
\hline \multirow[t]{6}{*}{ Gomphidae } & & 5 \\
\hline & Davidius & 1 \\
\hline & Merogomphus & 1 \\
\hline & Burmagomphus & 1 \\
\hline & Paragomphus & 1 \\
\hline & Nepogomphus & 1 \\
\hline \multirow{22}{*}{ Libellulidae } & & 33 \\
\hline & Acisoma & 1 \\
\hline & Brachydiplax & 2 \\
\hline & Brachythemis & 1 \\
\hline & Camacinia & 1 \\
\hline & Cratilia & 1 \\
\hline & Crocothemis & 1 \\
\hline & Diplacodes & 2 \\
\hline & Lathrecista & 1 \\
\hline & Lyriothemis & 1 \\
\hline & Neurothemis & 3 \\
\hline & Onychothemis & 1 \\
\hline & Orthetrum & 7 \\
\hline & Palpopleura & 1 \\
\hline & Pantala & 1 \\
\hline & Potamarcha & 1 \\
\hline & Rhyothemis & 2 \\
\hline & Tetrathemis & 1 \\
\hline & Tholymis & 1 \\
\hline & Tramea & 1 \\
\hline & Trithemis & 3 \\
\hline & Total & 44 \\
\hline
\end{tabular}

\begin{tabular}{|c|c|c|}
\hline \multicolumn{3}{|c|}{ Sub-order Zygoptera } \\
\hline Family & Genus & No. of species \\
\hline \multirow[t]{5}{*}{ Calopterygidae } & & 4 \\
\hline & Caliphaea & 1 \\
\hline & Echo & 1 \\
\hline & Matrona & 1 \\
\hline & Neurobasis & 1 \\
\hline \multirow[t]{4}{*}{ Chlorocyphidae } & & 6 \\
\hline & Libellago & 1 \\
\hline & Aristocypha & 3 \\
\hline & Heliocypha & 2 \\
\hline \multirow[t]{8}{*}{ Coenagrionidae } & & 20 \\
\hline & Aciagrion & 3 \\
\hline & Agriocnemis & 3 \\
\hline & Ceriagrion & 5 \\
\hline & Ischnura & 4 \\
\hline & Mortonagrion & 1 \\
\hline & Pseudagrion & 2 \\
\hline & Onychargia & 1 \\
\hline \multirow[t]{3}{*}{ Euphaeidae } & & 2 \\
\hline & Anisopleura & 1 \\
\hline & Euphaea & 1 \\
\hline \multirow[t]{3}{*}{ Lestidae } & & 3 \\
\hline & Indolestes & 1 \\
\hline & Lestes & 2 \\
\hline \multirow[t]{5}{*}{ Platycnemididae } & & 11 \\
\hline & Calicnemia & 4 \\
\hline & Coeliccia & 3 \\
\hline & Copera & 3 \\
\hline & Elattoneura & 1 \\
\hline \multirow[t]{3}{*}{ Platystictidae } & & 1 \\
\hline & Protosticta & 1 \\
\hline & Total & 46 \\
\hline
\end{tabular}


genera and 14 families (Table 3, also summarized in Table 4). Among the taxonomic categories, the genus Orthetrum was well-represented with seven species, while 36 of the 54 genera were represented with a single species, and the family Libeluilidae topped the list with 36 species (Table 4). Among Gomphidae, the species mentioned as "Stylogomphus sp." remains unidentified. It is distinct from the only Stylogomphus (S. inglisi Fraser, 1922) that is reported from India (Subramanian 2009).

We provide below our notes on the distribution, identification and status of a selection of species of special interest, e.g., Data Deficient species and others that have seldom been reported in literature, in the taxonomic order in which they appear in Table 3. This information may be useful when these species are assessed in the future by IUCN and other international and national conservation agencies. We also provide first descriptions of the female of Coeliccia schmidti and partially, a heterochromatic form of the female of Ischnura mildredae.

1. Chloropetalia selysi Fraser, 1929 (Chlorogomphidae) (Image 2): IUCN Red List status: Vulnerable (Dow 2009a).

The only record of this species from India, which is now more than 80 years old, was by Fraser (1936): "two males taken in company with C. preciousus (Fraser, 1924) and C. atkinsoni (Selys, 1878c) at Mungpoo [Darjeeling District], 3600ft., May 1927." Vick (1985) and St. Quentin (1970) added their records from Nepal: "According to Vick, in Nepal the species is "not necessarily rare but is hard to catch and probably missed altogether by nonspecialists". "The lack of recent records from India is likely to reflect a lack of expert sampling in Darjeeling over the last 70 years." (Dow 2009a). We recorded three individuals of this species: one male and a pair in copula, at Khonoma, Nagaland, on 14 May 2013. This species is rather easy to identify as it has segments 9-10 unmarked and segments 3-4 with two pairs of lunules, apical and postjugal.

2. Burmagomphus hasimaricus Fraser, 1926 (Gomphidae) (Image 2): IUCN Red List status: Data Deficient (Mitra 2010b).

The genus Burmagomphus Williamson, 1907 is represented in India by five species (Subramanian 2009). A male and a female of this species were observed in Intanki National Park. The teneral male was seen among grass adjoining the Intanki River which was more than $3.6 \mathrm{~m}$ wide. The female was seen sitting on vegetation at a height of around $2.7 \mathrm{~m}$. This species has not been recorded from India for 90 years since the type series was collected from Hasimara, West Bengal. The only other record is from Pokhara, Nepal (Vick 1985). Our record from Intanki extends the range of this species eastward by over $500 \mathrm{~km}$ and suggests that this species may occur in other northeastern states and northern Myanmar.

3. Merogomphus martini (Fraser, 1922)(Gomphidae) (Image 2): IUCN Red List status: Near Threatened. (Dow 2009c).

This gomphid was observed in Khonoma and Doyang. The abundance of M. martini in Khonoma was significantly greater in May 2013 than in May 2012: only one male was seen in 2012 while more than 17 males were seen in 2013. Adults were often seen resting on vegetation near small streams in the mountains. No female was observed, indicating their secretive habits or genuine rarity.

4. Matrona nigripectus Selys, 1879 (Calopterygidae) (Image 3): The genus Matrona Selys, 1853 has proven to be much more speciose than previously thought (Zhang \& Hämäläinen 2012). Currently, seven species are known (Schorr \& Paulson 2009). SJ observed several males and females of this species at Intanki NP in forested areas lurking in the shade, on 15-18 May 2012.

5. Aciagrion occidentale Laidlaw, 1919 (Coenagrionidae) (Image 5): IUCN Red List status: Least Concern (Mitra 2010a).

This species has been reported from Sri Lanka, India, Cambodia, Thailand and Vietnam (Mitra 2010a), although some Indochinese records may be misidentified as $A$. borneese. From India it is recorded from several localities in southern and central India, and recently from Odisha (previously Orissa; Nair 2011). In the original description of this species, under the name "Aciagrionhisopa (Selys) ? race occidentalis", from Castle Rock, N. Kanara District, Bombay; Parambiculam, Cochin State; Trichur, Cochin State) Laidlaw (1919) stated that it is "characterised by having a black triangle on the dorsum of the eight abdominal segment, with its apex directed towards the end of the segment, and extending nearly to the full length of the segment". However, in his later review of the genus, referring to males of this species from Cochin and Ceylon, he made the following correction (Laidlaw 1924: 6): "My description states that the black mark on segment eight of the abdomen has its apex directed toward the hinder end of segment. This should read "directed towards the base of the segment". He also provided a drawing with a triangle at the segment apex directed towards its base, and also with a black mark at S10 (Laidlaw, 1924: Fig. 16). The pattern of S7 and S10 corresponds to Aciagrion paludense Fraser, 1922, considered by a 


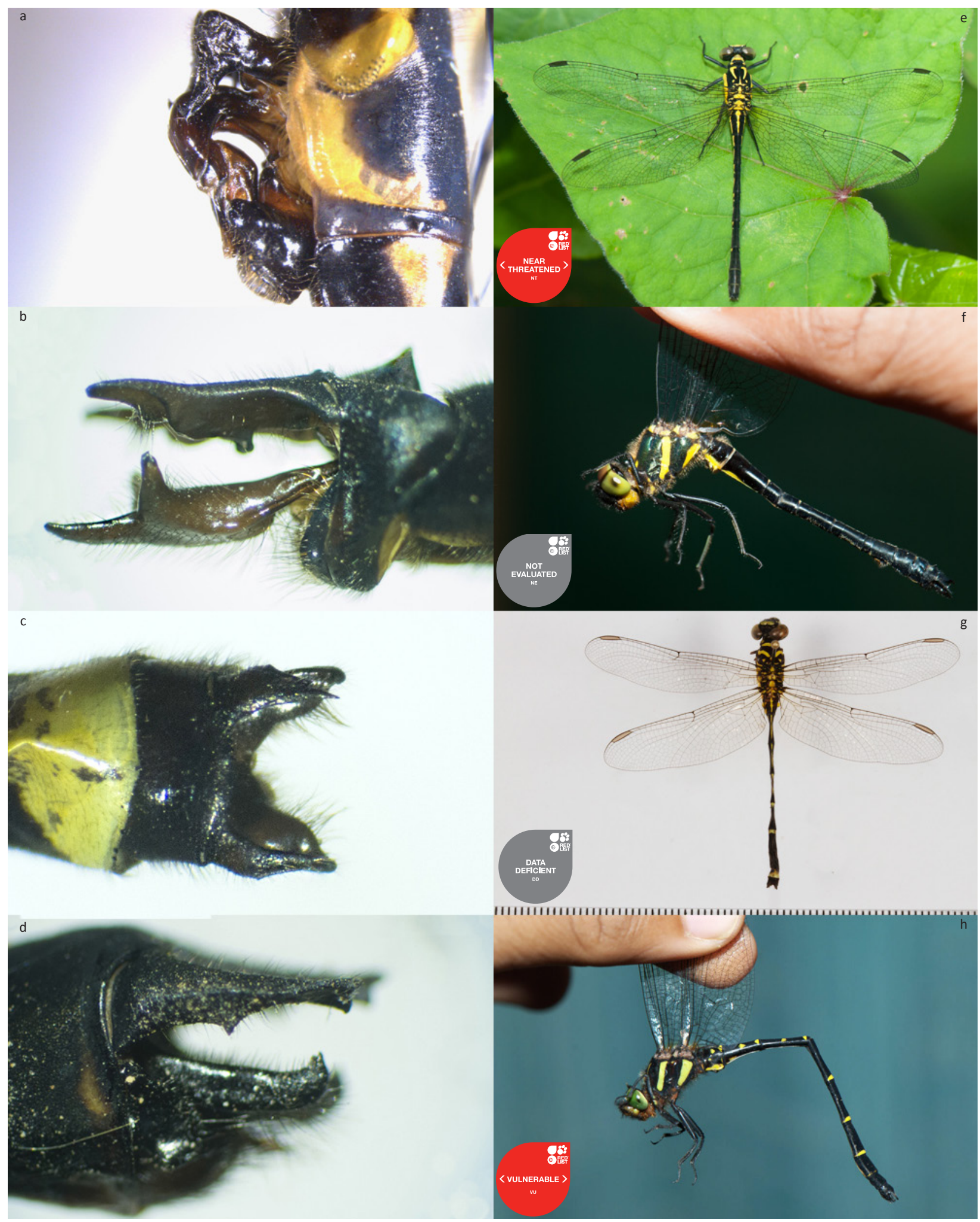

Image 2 a-h. Odonata of Nagaland. (Families: Gomphidae, Genera Incertaesedis and Chlorogomphidae).

$\mathrm{a}$ - the secondary genetalia of the male; $\mathrm{b}-\mathrm{d}$ - anal appendages; ( $\mathrm{e}-\mathrm{h}$ - adult male) e - Merogomphus martini; $\mathrm{f}$ - Idionnyx stevensi; g - Burmagomphus hasimaricus; $\mathrm{h}$ - Chloropetalia selysi. (C) Shantanu Joshi 


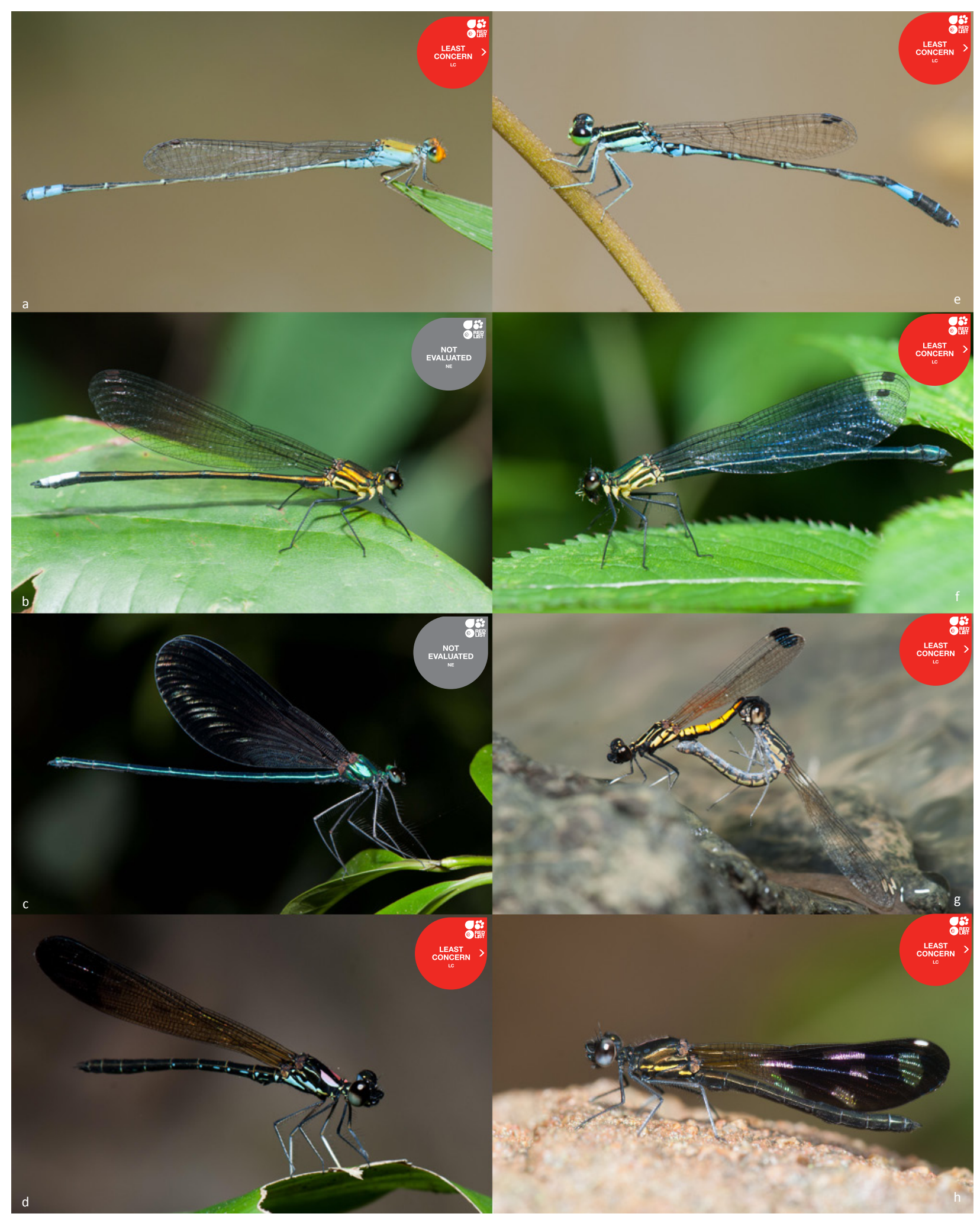

Image 3. Odonata of Nagaland. Families: Coenagrionidae, Calopterygidae and Chlorocyphidae

a - Pseudagrion rubriceps; b - Caliphaea confuse male; c - Matrona nigriceptus; d - Heliocypha biforata; e - Mortonagrion aborense;

$\mathrm{f}$ - Caliphaea confusa female; $\mathrm{g}$ - Libellago lineata copula; $\mathrm{h}$ - Aristocypha quadrimaculata. () Shantanu Joshi 
junior synonym of $A$. occidentale (Laidlaw 1924; Fraser 1933). In Intanki NP on 24 May 2013 SJ recorded an Aciagrion male with S7 having a black triangle directed to the end of the segment (Image 5), as in the original description of occidentale by Laidlaw (1919). This fact made us suppose that this description was correct and the later correction by Ladilaw (1924) was based on other specimens, with the opposite direction of the triangle. The enigma with two types of the S7 black triangle in Aciagrion spp. is to be investigated. It is not excluded that two species are in fact involved, named $A$. occidentale and $A$. paludense, respectively. For the time being we use for our specimen the name $A$. occidentale which anyway corresponds to the original description by Laidlaw (1919).

6. Ceriagrion rubiae Laidlaw, 1916 (Coenagrionidae) (Image 5): IUCN Red List status: Not assessed.

This Ceriagrion species has a very interesting disjunct distribution. It occurs in the Western Ghats and in Tamil Nadu (Babu et al. 2013), but has been reported once from Koraput in the Eastern Ghats, Odisha (Srivastava \& Das 1987). SJ recorded dozens of specimens of this species around paddyfields and ponds just outside Intanki National Park in May 2013. Several pairs in copulae were also observed ovipositing on aquatic vegetation. This is a range extension for the species by several hundred kilometers, and the first record from northeastern India. The male of this species can be easily separated from the similar $C$. praetermissum (Lieftinck) by its green eyes, longer abdomen and nonbifid inferior appendages (Asahina 1967).

7. Ischnura mildredae Fraser, 1927 (Coenagrionidae) (Images 4, 5): IUCN Red List status: Not assessed.

This species, and possibly the species group, has rather been neglected by most authors. There is considerable uncertainty about the taxonomic status of several species in this group. According to Vick (1986), “Asahina 1970 placed carpentieri, annandalei in synonomy with mildredae, which he considered as a sub-species of rufostigma, considering that the colour pattern differences were due to individual variation and states of maturity of the available material. This decision was followed by Davis \& Tobin (1984). However, this analysis does not take into account the structural differences that exist between these four taxa". Vick (1986) provided several diagrams and explanations to treat these four taxa as distinct species, an arrangement that we are following here. Later, Asahina (1991) downgraded mildredae back to subspecies, noting that none of the isochromatic females that he studied had a "large bluish spot on dorsum of the segment 8" as noted by Fraser (1933). In our specimens, most females had a small pale spot on segment 8 , but never blue as Asahina had noted. We don't think that this character alone is sufficient to treat mildredae as a subspecies. We found this species to be very common around ponds in Khonoma in May 2013. We saw several dozen specimens at a small pond that was used to breed fishes, where several pairs in copulae were also observed. These specimens closely matched the images and descriptions by Fraser (1933) and Vick (1986). All the males had a small blue spot on segment 8 that is characteristic of I. mildredae. Fraser (1933) and Vick (1986) did not mention a heterochromatic form for this species. However, we observed several females of a heterochromatic form, which was similar to the heterochromatic forms of related species, and may be described as follows (also see Images 4, 5): prothorax and thorax broadly black on dorsum. A broad, blackishbrown dark band present between the eyes. Segments 3-10 dorsally black, with pale annules. Segment 2 with a characteristic marking shaped like a mushroom on the dorsal side towards the end of the segment.

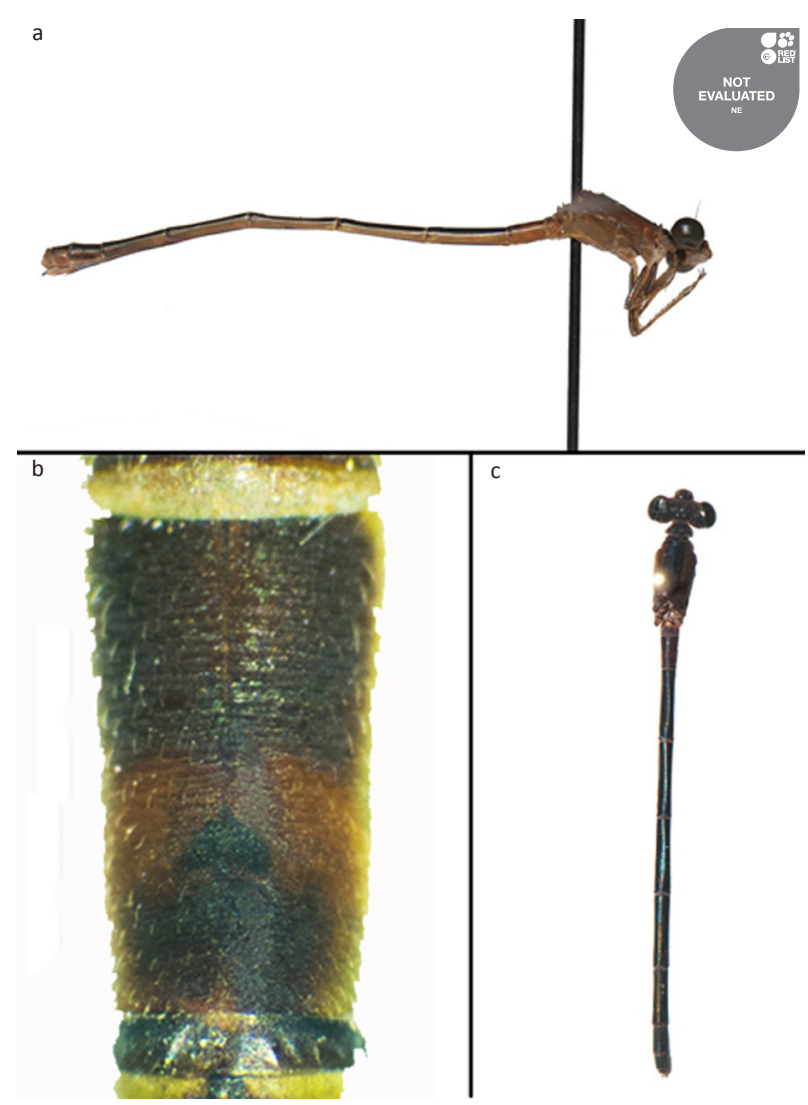

Image 4. Heterochromatic female of Ischnura mildredae a - lateral; b close-up of the second Abdominal Segment; c - dorsal (C) Shantanu Joshi 


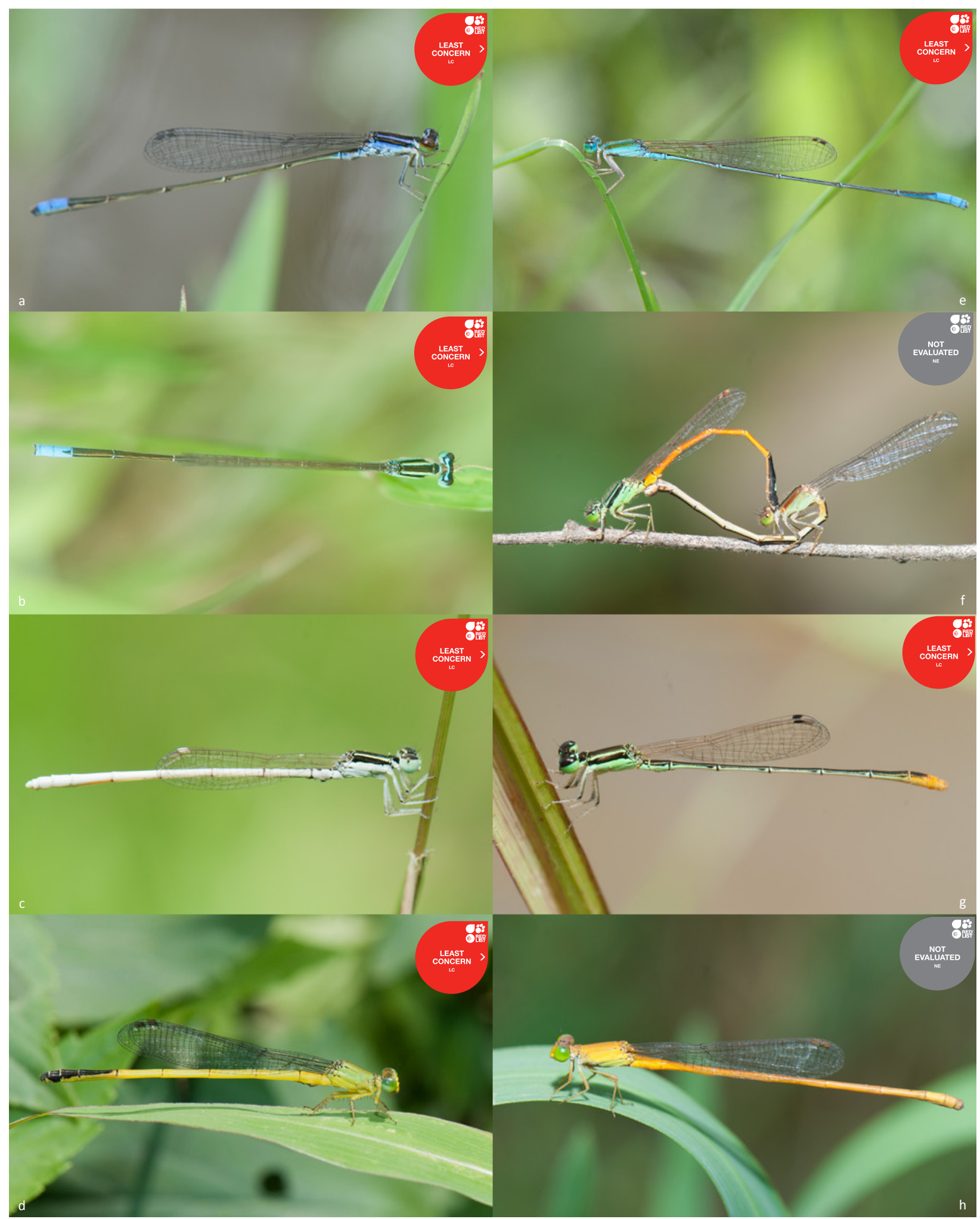

Image 5. Odonata of Nagaland. Family: Coenagrionidae

a - Aciagrion approximans; b - Aciagrion occidentale; c - Agriocnemis pieris; d - Ceriagrion fallax; e - Aciagrion pallidum;

f - Ischnura mildredae; g - Agriocnemis femina; h - Ceriagrion rubiae. (C) Shantanu Joshi 


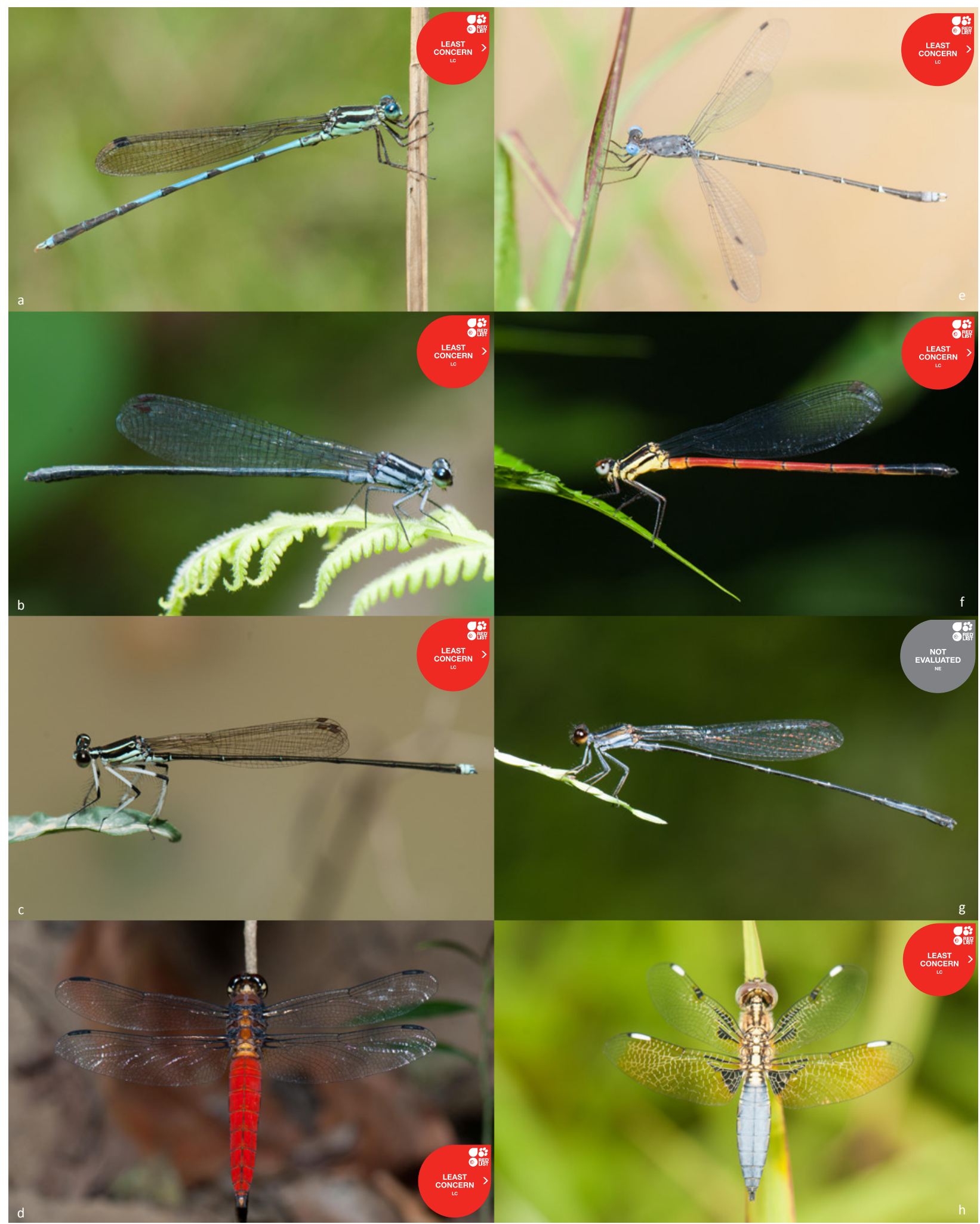

Image 6. Odonata of Nagaland. Families: Lestidae, Platycnemididae and Libellulidae

a - Indolestes cyaneus; b - Calicnemia imitans; c - Copera ciliata; $\mathrm{d}$ - Lyriothemis bivittata; e - Lestes praemorsus; f - Calicnemia erythromelas; g - Elattoneura coomansi; h - Palpopleura sexmaculata. (C) Shantanu Joshi 


\section{Indolestes cyaneus Selys, 1862 (Lestidae) (Image} 6): IUCN Red List status: Least Concern (Dow 2009b).

This species has been previously reported in India from Punjab and Simla eastward to Tiger Hills in Darjeeling, and outside in Nepal, Bhutan and Taiwan (Mitra 2002; Dow 2009b). However, it has not yet been formally reported from northeastern India. We observed it in Dzulekie on a tar road from Dzulekie to Benreu but did not find it elsewhere. Males were more commonly encountered than females: seven males and only two females were seen on 4 May 2012. Fraser (1933) had found this species breeding in "swift cold mountainstreams", whereas we observed two pairs in copulae oviposting in a small puddle adjacent to the tar road, at a considerable distance from the forest streams.

9. Calicnemia erythromelas Selys, 1891 (Platycnemididae) (Image 6): IUCN Red List status: Least Concern (Wilson 2009).

This species has so far been recorded from Thailand (Hämäläinen \& Pinratana 1999), Vietnam (Asahina 1997), China (Sui \& Sun 1984) and Myanmar (Fraser 1933). Its type locality is Leiktho, Toungoo District, Myanmar, and Fraser recorded it from several other localities in Myanmar. However, there have not been any prior records from India, and it was not listed among Indian odonates by Subramanian (2009). We recorded one male of this species in Khonoma on a cloudy day on the road from Khonoma to Mezoma on 17 May 2013. Our record represents an addition to the Indian odonate fauna, and the first record of the species from the Myanmar-northeastern Indian region in several decades. However, it is unsurprising to find this species in Nagaland, which adjoins Myanmar, and we suspect that more records will turn up as this area is further surveyed in the future.

10. Coeliccia schmidti Asahina, 1984 (Platycnemididae) (Image 7): IUCN Red List status: Data Deficient (Dow 2009d).

This species was described from "Chabong, Khunou, Manipur-Staat, 1200 ft." (Asahina 1984), which is presumably near Imphal, Manipur. SJ observed several individuals at Intanki NP between 15 and 18 May 2012. Unfortunately, all the voucher specimens were destroyed by ants, so we have no specimens to study now. The following observations are based on SJ's photographs and field notes. The characters differing from Asahina's description are given below for the male, and the female is described here for the first time.

Male: Distal half of segment nine and the whole of segment 10 bright yellow, not reddish-brown as mentioned by Asahina (Asahina's description of the color may be ascribed to post-mortem changes). Anal appendages are yellow, the structure matching illustrations in the original species description by Asahina. The color of the paraproct apex was variable: three specimens showed dark apices, two did not.

Female: Head: Vertex with a series of six pale blue spots: two between the anterior and the outer ocelli, two narrowly separated from the spots between the anterior and the outer ocelli and extending on the outer ocelli, and two spots on the outside of the outer ocelli. Eyes: black above, brilliant blue below. The spots on the posterior side of the head are large, similar to the male. Thorax: Prothorax: broadly citron-yellow. Posterior lobe citron-yellow above, black on sides. Pterothorax: two narrow pale blue antehumeral stripes, which gradually turn pale yellow posteriorly in some specimens while remaining pale blue in others (exact data on number of specimens of each type is unavailable due to loss of specimens as mentioned before). Mesepimeron and areas below citron yellow. Abdomen: blackish-brown for most part, pale brown below. Segments 2-8 with paired faint brown spots on dorsum. Segments nine and 10 fully yellow. Anal Appandages: black, short, like in the other female Coeliccia.

Distinguishing Characters: Coeliccia is a fairly large and complex genus, with 11 species so far known from

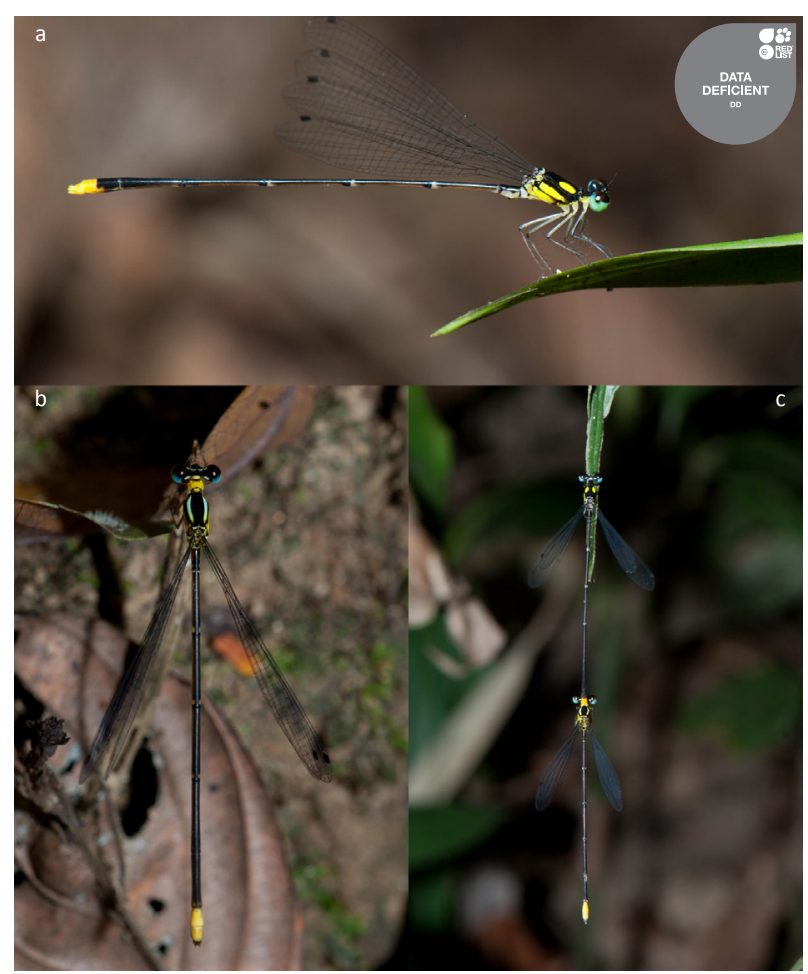

Image 7. Coeliccia schmidti Asahina, 1984. a - male; b - female; c- in copula. (C) Shantanu Joshi 


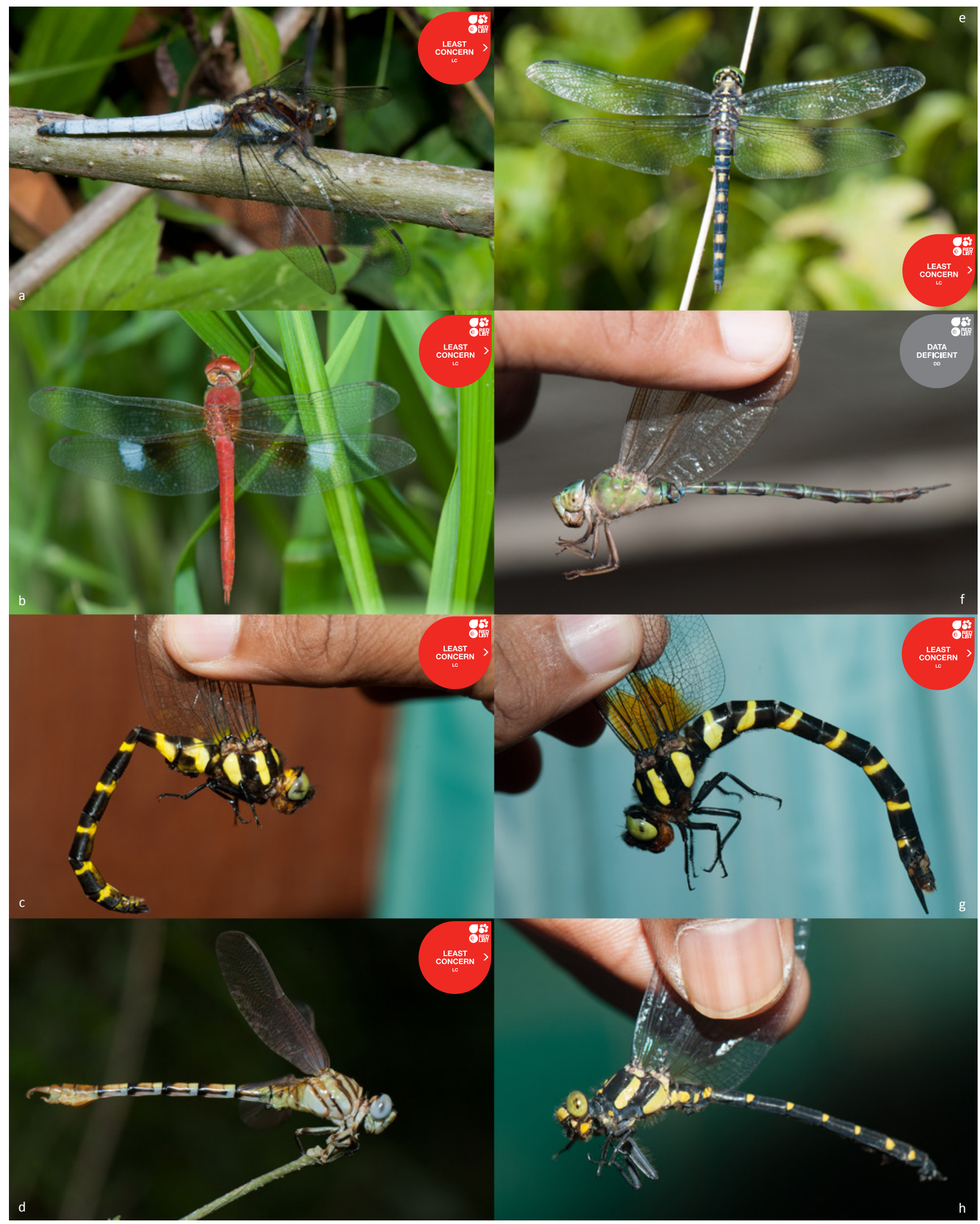

Image 8. Odonata of Nagaland. Libellulidae, Aeshnidae, Cordulegasteridae and Gomphidae.

a - Orthetrum japonicum; b - Tholymis tillarga; c - Anotogaster nipalensis male; $\mathrm{d}$ - Paragomphus lineatus; e - Onychothemis testacea;

f - Gynacantha bainbriggei; g - Anotogaster nipalensis female; $\mathrm{h}$ - Stylogomphus sp. C Shantanu Joshi 
India (Subramanian 2009). Without re-assessment of old specimens and studies of fresh material, a satisfactory key to this genus cannot be made. However, from the information currently at hand, the males of this species can be separated from other Coeliccia species by very large pale spots on dorsum of thorax and four small spots in the ocellar region. Female has a completely yellow prothorax which separates it from females of all Indian Coeliccia except for $C$. fraseri Laidlaw, 1932 and $C$. renifera (Selys, 1886). Of these, $C$. fraseri has segments nine and 10 black and $C$. renifera has segment 10 black, unlike in $C$. schmidti where both the segments are bright yellow. $C$. schmidti resembles $C$. renifera and $C$. loogali Laidlaw, 1932 in having six spots in the ocellar region.

11. Elattoneura coomansi Lieftinck, 1937 (Platycnemididae) (Image 7): IUCN status: Not assessed.

The distribution of this species is not well known, very few records have been published, and nothing is known about its habits. Prasad \& Varshney (1995) gave the distribution as "India". We observed several males and females of this species at Intanki National Park, including many pairs in copulae that were ovipositing in the submerged vegetation at Intanki River.

\section{REFERENCES}

Asahina, S. (1967). A revision of the Asiatic species of the damselflies of the genus Ceriagrion (Odonata, Agrionidae). Japanese Journal of Zoology 15(3): 255-334, figs. 1-237

Asahina, S. (1984). Assamese and Burmese Coeliccia species in the collection of Dr. Erich Schmidt (Odonata: Platycnemididae). Transactions Shikoku Entomological Society 16 (4): 1-9, figs. 1-26.

Asahina, S. (1991). A taxonomic revision of the Ischnurarufostigma group of southeast. Asia Tombo 34(1-4): 2-22, figs. 1-88.

Asahina, S. (1997). Records of Northern Vietnamese Odonata taken by the expedition members from the National Science Museum, Tokyo. 5: Coenagrionidae, Protoneuridae, and PlatycnemididaeBulletin National Science Museum Tokyo, Series A: Zoology 23(1): 17-3

Carle, F.L. (1995). Evolution, taxonomy, and biogeography of ancient Gondwanian Libelluloides, with comments on Anisopteroid evolution and phylogenetic systematics (Anisoptera: Libelluloidea). Odonatologica 24(4): 383-424.

Dijkstra, K.D.B., V.J. Kalkman, R.A. Dow, F.R. Stokvis \& J. van Tol (2013) Redefining the damselfly families: the first comprehensive molecular phylogeny of Zygoptera (Odonata). Systematic Entomology 39(1): 68-96; http://dx.doi.org/ 10.1111/syen.12035

Dow, R.A. (2009a). Chloropetalia selysi. In: IUCN 2013. IUCN Red List of Threatened Species. Version 2013.1. <www.iucnredlist.org>. Downloaded on 15 September 2013

Dow, R.A. (2009b). Indolestes cyaneus. In: IUCN 2012. IUCN Red List of Threatened Species. Version 2012.2. <www.iucnredlist.org> Downloaded on 10 February 2013.

Dow, R.A. (2009c). Merogomphus martini. In: IUCN 2013. IUCN Red List of Threatened Species. Version 2013.2. <www.iucnredlist.org>. Downloaded on 17 May 2014.
Dow, R.A. (2009d). Coeliccia schmidti. In: IUCN 2013. IUCN Red List of Threatened Species. Version 2013.2. <www.iucnredlist.org>. Downloaded on 17 May 2014.

Fraser, F.C. (1933, 1934, 1936). The Fauna of British India including Ceylon and Burma: Odonata, Volumes 1, 2 \& 3. Taylor and Francis Ltd., London, 423pp, 398pp, 461pp.

Grewal, B., R. Sreenivasan \& B. Haralu (2012). Nagaland Biodiversity \& Conservation Programme, an Action Document. M.Sc. Wildlife Biology and Conservation, Wildlife Conservation Society-India Programme, National Centre for Biological Sciences, Bangalore. Department of Forests, Ecology, Environment and Wildlife, Nagaland, 153pp.

Lahiri, A.R. (1977). On a collection of Odonata from Manipur with new records. Records of Zoological Survey India, Occasional Paper no. 72: 408-418.

Lahiri, A.R. (1987). Studies on the Odonate fauna of Meghalaya. Records Zoological Survey India, Occasional Paper no. 99: 1-402.

Laidlaw, F.F. (1919). A list of the dragonflies recorded from the Indian Empire, with special reference to the collection of the Indian Museum. Part II (contd). The family Agrionidae. B. The legions Argia and Agrion. Records of the Indian Museum (a Journal of Indian zoology) 16: 169-195.

Laidlaw, F.F. (1924). Notes on the Oriental dragonflies of the genus Aciagrion. Proceedings of the United States National Museum 66(10): 1-9.

Laidlaw, F.F. (1950). A survey of the Chlorocyphidae (Odonata: Zygoptera), with diagnoses of proposed new genera, and description of a new geographical subspecies. Transactions of the Royal Entomological Society of London 101(8): 257-280.

Mitra, T.R. (2002). Geographical distribution of Odonata (Insecta) of Eastern India. Memoirs of Zoological Survey of India 19(9): 208pp.

Mitra, A. (2010a). Aciagrionoccidentale. In: IUCN 2012. IUCN Red List of Threatened Species. Version 2012.2. <www.iucnredlist.org>. Downloaded on 21 June 2013.

Mitra, A. (2010b). Burmagomphushasimaricus. In: IUCN 2013. IUCN Red List of Threatened Species. Version 2013.2. <www.iucnredlist. org>. Downloaded on 17 May 2014.

Mitra, T.R., M. Prasad \& C. Sinha (2006). Odonata of Nagaland, Fauna of Nagaland, State Fauna Series. Zoological Survey of India 12: 7587.

Nair, M.V. (2011). Dragonflies \& Damselflies of Orissa and Eastern India. Wildlife Organisation, Forest \& Environment Department, Government of Orissa, 252pp.

Prasad, M. \& R.K. Varshney (1995). A check list of the Odoanta of India including data on larval studies. Oriental Insects 29: 385-428

Schorr, M. \& D. Paulson (2009). World Odonata List. http://www. pugetsound.edu/x6140.xml. Accessed on 25/05/2013. Last revised on $07 / 05 / 2013$.

Subramanian, K.A. (2009). A Checklist of Odonata of India. Zoological Survey of India, 36pp.

Subramanian, K.A. (2014). A Checklist of Odonata of India. Zoological Survey of India, Kolkata, 31pp.

Sui, J.C. \& H.G. Sun (1984). Common species of dragonflies from China. Agriculture Publ. House, 341 pp.

Vick, G.S. (1985). Odonata collected by the Shiplake College Trekking Society Expedition to Nepal in 1984. Notulae Odonatologicae 2(5): 80-82.

Vick, G.S. (1986). Records of Nepalese Odonata in 1985. Notulaeod Onatologicae 2(7): 114-115.

Wilson, K.D.P. (2009). Calicnemia erythromelas. In: IUCN 2012. IUCN Red List of Threatened Species. Version 2012.2. <www.iucnredlist. org>. Downloaded on 26 May 2013. 